\title{
LYON NATURAL RADIOCARBON MEASUREMENTS II
}

\section{J. EVIN, R. LONGIN, G. MARIEN, and Ch. PACHIAUDI}

Laboratoire de Radiocarbone, Institut de Physique Nucléaire 69-Villeurbanne, France

INTRODUCTION

The Radiocarbon Dating Laboratory of the Department of Geology, University of Lyon, is going on with work since its foundation in 1965, in the basement of the Nuclear Physics Institute.

The present list includes geologic and archaeologic samples measured from 1968 to 1970 , most of the water samples measured since 1966 and a range of bone samples measured to try a new collagen preparation method which the abstract is given below.

The wood and shell samples preparation method and the counting technique $\left(\mathrm{CO}_{2}\right.$ in $0.5 \mathrm{~L}$ proportional counter $)$ have not been really modified and were already described in Lyon I (R., 1969, v. 11, p. 112 117). The background of the two counters has been lowered and better stabilized by a new setting of discrimators. The new backgrounds are respectively $3.20 \pm 0.05$ and $2.20 \pm 0.05 \mathrm{cpm}$.

Two new detectors will be set up. One is a proportional counter of large effective volume ca. 40,000 yr limit ages; the other one is a Packard liquid scintillation spectrometer Model 3320 Tricarb. The characteristics of these two detectors and a description of the chemical bench for benzene preparation will be given in the next date list. The Radiocarbon Laboratory has, since May 1970, a mass spectrometer Model A.E.I., MS 20 Isotopic, which will ensure $\mathrm{C}^{13}$ measurements for all the samples.

Ages are calculated using the half-life value 5570 with A.D. 1950 as reference year. The statistical errors, corresponding to one standard deviation, include the contribution of the contemporary standard, background, and sample counting.

\section{ACKNOWLEDGMENTS}

We are grateful to J. Flandrin of the Dept. of Geology for his continuous support and to A. Sarazin, Dir., Nuclear Physics Institute, for his welcome and the technical and financial help of his Institute.

Also, we thank all the staff of the Institute, especially Messrs. Viano and Devesa for their technical help.

\section{SAMPLE DESCRIPTIONS}

I. GEOLOGIC SAMPLES

A. Rhōne Alpes region

\section{Ly-113. Rouelbeau, Canton de Genève}

Wood from peaty layer with volcanic ash, interbedded in lacustrine chalk, at Rouelbeau, near Jussy, canton of Genève $\left(46^{\circ} 14^{\prime} \mathrm{N}\right.$ Lat, $6^{\circ} 14^{\prime}$ 
E Long). Coll. 1964 and subm. 1967 by A. Jayet, Chemin du Pré Catellier 9, Genève. Comment: much younger than expected by assoc. volcanic ash which supposedly were from Laachersee (Eifel) of Aller $\phi d$ age (Martini and Duret, 1965).

\section{Ly-116. Veigy, Haute-Savoie}

$9180 \pm 200$

Pinus sylvestris cone included in lacustrine chalk $10 \mathrm{~cm}$ below volcanic ash at Veigy, Haute-Savoie $\left(46^{\circ} 16^{\prime} \mathrm{N}\right.$ Lat, $6^{\circ} 15^{\prime} \mathrm{E}$ Long). Coll. 1964 by J. Martini and J. J. Duret; subm. 1967 by A. Jayet. Before subm. sample was kept in glycerin. Comment: ash suggested Aller $\phi d$ age. Date is too young but may be due to defective elimination of the glycerin.

\section{Ly-277. Cuculianne, Hautes-Alpes}

$11,250 \pm 250$ 9300 в.c.

Fragment of tree trunk from a thick detrital deposit in Le Buech torrent bed at Cuculianne near Eyguians, Hautes-Alpes $\left(44^{\circ} 21^{\prime} \mathrm{N}\right.$ Lat, $5^{\circ} 46^{\prime}$ E Long). Coll. and subm. by G. Montjuvent, Inst. Dolomieu, Grenoble. Comment (G.M.): agrees with Postglacial or Aller $\phi$ d age of the main alluviation phase of Le Buech torrent.

\section{Ly-237. Quaix, Isère}

$\geqslant 31,500$

Fragment of larch trunk inbedded in a clayey, sandy layer during Würm retreat at Peteysset near Quaix, Isère $\left(45^{\circ} 15^{\prime} \mathrm{N}\right.$ Lat, $5^{\circ} 44^{\prime} \mathrm{E}$ Long). Coll. by M. Collardel and subm. 1968 by A. Bocquet, Grenoble. Comment: date older than expected; implies earlier Würm glacier retreat or redeposition of old wood.

\section{Ly-114. Saint Jean, Genève}

$\geqslant 31,000$

Fragment of tree-trunk inbedded in an interglacial deposit $-40 \mathrm{~m}$

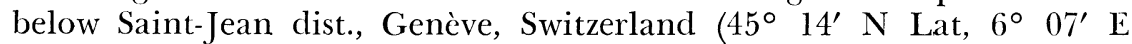
Long). Coll. 1964 by J. Duret and subm. 1967 by A. Jayet. Comment: as expected, (Jayet, 1966) date seems to exclude Würm IV age for overlying glacial deposits.

\section{Chevillys series, Haute-Savoie}

Samples from clayey, sandy interglacial sediment $15 \mathrm{~m}$ thick at Chevillys near Lathuile, Haute-Savoie ( $45^{\circ} 48^{\prime} \mathrm{N}$ Lat, $6^{\circ} 12^{\prime} \mathrm{E}$ Long). Coll. and subm. 1967 by A. Brun, Lab. de Géol. Dynam., Fac. Sci., Paris.

\section{Ly-139. Chevillys I} $510 \mathrm{~m})$.

Wood from a lignitic layer in upper part of interglacial series (alt

\section{Ly-140. Chevillys 3C}

Fine lignitic debris from the lower part of the series (alt $500 \mathrm{~m}$ ). General Comment: interglacial series is overlain by a supposed Würm moraine (Bourdier, 1963). Minimum age eliminates attribution of series to interstadial found at Armoy, Haute-Savoie (Blavoux and Brun, 1966) and dated Gif-333: 23,500 \pm 1200 . 


\section{B. Other regions}

\section{Ly-281. La Maxe, Moselle}

$8660 \pm 160$

6710 B.c.

Wood from alluvions in Moselle $\mathrm{R}$. lower terrace at La Maxe, Moselle (48 $51^{\prime} \mathrm{N}$ Lat, $6^{\circ} 12^{\prime} \mathrm{E}$ Long). Coll. and subm. 1969 by $\mathrm{R}$. Haghighate, Bur. Recherches Géol. et Min., Metz. Comment: agrees with expected Postglacial age of terrace.

Ly-243. Vik, Cameroun

$\geqslant \mathbf{3 0 , 0 0 0}$

Oyster shells from $-20 \mathrm{~m}$ depth in a well dug in a clayey, sandy Quaternary series at Vik, Dept. de Logone et Chari, N Cameroun (12 ${ }^{\circ} 31^{\prime} \mathrm{N}$ Lat, 14ㅇ $36^{\prime} \mathrm{E}$ Long). Coll. and subm. 1969 by R. Biscaldi, Bur. de Recherches Géol. et Min., Montpellier.

\section{Golfe de Gascogne series}

Unbroken marine shells assoc. with sand and gravel, from continental plateau of Gascogne Gulf between Ré I. and Rochebonne Plateau. Coll. 1968 and subm. 1969 by J. P. Barusseau, Centre de Recherches de Séd. Marine, Perpignan.

\section{Ly-168. T H E 22}

$6080 \pm 200$

$\left(46^{\circ} 25^{\prime} \mathrm{N}\right.$ Lat, $1^{\circ} 59^{\prime} \mathrm{W}$ Long) $-32 \mathrm{~m}$

4130 B.c.

Ly-171. T H E 146

$\geqslant 6280 \pm 200$

$\left(46^{\circ} 20^{\prime} \mathrm{N}\right.$ Lat, $2^{\circ} 05^{\prime} \mathrm{W}$ Long) $--53 \mathrm{~m}$

4330 B.C.

Comment: value calculated only after $20 \mathrm{hr}$ counting before elimination of eventual Radon activity.

\section{Ly-169. T H E 128}

$8240 \pm 220$

$\left(46^{\circ} 12^{\prime} \mathrm{N}\right.$ Lat, $2^{\circ} 08^{\prime} \mathrm{W}$ Long $)-46 \mathrm{~m}$

\section{Ly-170. T H E 139}

6290 B.C.

$\left(46^{\circ} 13^{\prime} \mathrm{N}\right.$ Lat, $1^{\circ} 59^{\prime} \mathrm{W}$ Long $)-41 \mathrm{~m}$

$19,960 \pm 400$

18,010 B.C.

General Comment (J.P.B.): all measured shell species are shallow-water or littoral. Their fragility excludes any important transport. Dates make evident several ancient shores between 6000 and 20,000 B.P. (Barusseau, 1969). Ly-168 and Ly-171 should be contemporary with Salpausselkä episode.

$$
\text { II. ARCHAEOLOGIC SAMPLES }
$$

\section{A. Historic and Bronze-age periods}

\section{Ly-272. Doué la Fontaine, Maine et Loire}

$1210 \pm 100$

A.D. 740

Charcoal from a building inside a feudal clod at La Motte de la Chapelle near Doué la Fontaine, Maine et Loire $\left(47^{\circ} 11^{\prime} \mathrm{N}\right.$ Lat, $0^{\circ} 18^{\prime}$ W Long). Coll. and subm. 1969 by M. de Boüard, Centre de Recherche Archéol., Univ. de Caen. Comment (M.deB.): a little older than sup- 
posed destruction of building (ca. A.D. 900); but measurement was performed in order to invalidate ca. A.D. 1120, which was also possible.

Ly-267. Les Kéllia Qouçour 'Isā, Sud I 5.50 W

$1645 \pm 80$

Charcoal from kitchen of coptic monastery Les Kéllia near Markaz

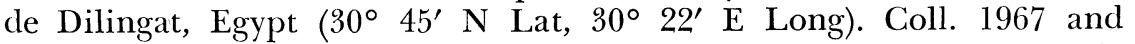
subm. 1968 by D. Weidmann, Lausanne, Switzerland. Comment (D.W.): kitchen was occupied till A.D. 600 , date seems to prove that woods from an old building was burnt later in kitchen. Compare with B-988: 1530 \pm 100 (R., 1970, v. 12, p. 381).

\section{Ly-152. Saint Romain en Gal, Rhone}

$1690 \pm 100$

Charcoal from a timber, burned at destruction time (ca. A.D. 250) of Gallo-Roman town at Saint-Romain en Gal, Rhōne $\left(45^{\circ} 32^{\prime} \mathrm{N}\right.$ Lat, $4^{\circ} 51^{\prime}$ E Long). Coll. and subm. by R. Chalavoux, Lyon.

\section{Ly-72. Magny sur Tille, Cote d'Or}

Charcoal from refuse pit assoc. with Hallstatt industry at Le Marais

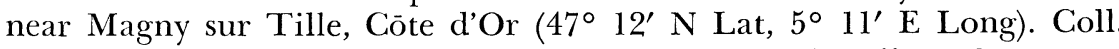
and subm. 1966 by R. Ratel, Lab. de Géol., Fac. Sci., Dijon. Comment: agrees with expected age and assoc. industry.

\section{Chaumes les Baigneux series, Cote d'Or}

Charcoal from supposed Late Bronze tumulus at La Forēt near

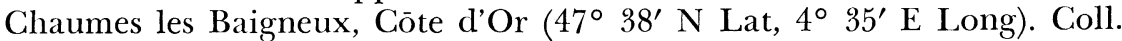
and subm. 1966 by R. Ratel.

\section{Ly-80. Chaumes les Baigneux, Central hearth A.D. 1580}

$$
370 \pm 150
$$

Sample from hearth found in middle of tumulus, no assoc. industry.

\section{Ly-94. Chaumes les Baigneux, Basal hearth}

$2320 \pm 100$

Samples from hearth found at bottom of tumulus.

General Comment: Ly-80 is obviously wrong, Ly-94 seems too young for expected Late Bronze age, but agrees with Gif-1 109 (550 в.c.) measured on the same sample.

\section{Ly-135. Chène de la Balme, Savoie}

$2880 \pm 220$

Fragment of branch of oak tree found in alluvions of Rhōne bed

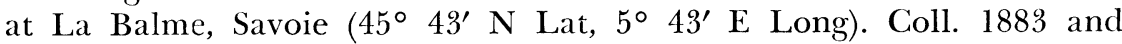
subm. by L. Lagier-Bruno Yenne, Savoie (Lagier-Bruno, 1970). Comment: compare with Gif-386: $2870 \pm 200$ (R., 1969, v. 11, p. 332).

\section{Les Sarrasins series, Isère}

Charcoal from grotto Les Sarrasins near Seyssinet-Pariset, Isère $\left(45^{\circ} 10^{\prime} \mathrm{N}\right.$ Lat, $5^{\circ} 4 \mathrm{1}^{\prime} \mathrm{E}$ Long). Coll. and subm. 1969 by A. Bocquet, Grenoble. 
Ly-238. Les Sarrasins, Level 4C

$2940 \pm 170$

Assoc. with Late Bronze II industry.

Ly-239. Les Sarrasins, Level 5

Assoc. with industry of beginning of Late Bronze age.

General Comment: both dates confirm that Grenoble region Late Bronze age is contemporaneous and not delayed with respect to other French regions (Bocquet and Papet, 1966).

\section{Ly-84. Lithaire, Manche}

$2030 \pm 150$

80 B.C.

Charcoal lying on flagging of an "Allée Couverte" at Le Plessis near Lithaire, Manche (49 $17^{\prime} \mathrm{N}$ Lat, $1^{\circ} 36^{\prime} \mathrm{W}$ Long). Coll. and subm. 1967 by B. Edeine, Caen. Comment (B.E.): date proves that "Allée Couverte" was reoccupied much later than erection.

\section{Ly-83. Flamanville, Manche}

$2660 \pm 220$

710 B.C.

Charcoal from $-60 \mathrm{~cm}$ level in hearth at Le Castel, near Flamanville, Manche $\left(49^{\circ} 32^{\prime} \mathrm{N}\right.$ Lat, $1^{\circ} 44^{\prime} \mathrm{W}$ Long). Coll. and subm. by $\mathrm{B}$. Edeine. Comment (B.E.): agrees with assoc. Bronze industry.

\section{Ly-233. Sous-Sac, Ain}

$3260 \pm 100$

1310 в.c.

Calcareous tuffa from rock-shelter Sous-Sac, near Craz de Michaille, Ain $\left(46^{\circ} 02^{\prime} \mathrm{N}\right.$ Lat, $5^{\circ} 46^{\prime} \mathrm{E}$ Long). Coll. 1962 by G. Sanlaville and subm. 1967 by R. Vilain, Lab. de Géol., Fac. Sci. Lyon. Comment: tuffa contained fragment of Middle Bronze age pottery with which the date agrees well despite fact that a calcareous tuffa theoretically contains some dead carbon.

\section{B. Pile düellings of French alpine lake}

The following samples come from several coastal stations submerged in French alpine lakes. They were coll. and subm. in 1967 or 1968 by R. Laurent, Centre de Recherche Archeol. Lacustre, Tréserves, Savoie.

\section{Ly-189. Aiguebelette, 145 B2, Savoie}

$$
1860 \pm 70
$$

Fragment of wood submerged near island La Tour de Beauphare, $S$ part of Aiguebelette Lake near Lepin, Savoie $\left(45^{\circ} 33^{\prime} \mathrm{N}\right.$ Lat, $5^{\circ} 48^{\prime}$ E Long). Comment: object was found close to, but outside, a Chalcolithic settlement. Date suggests occupation of Tour de Beauphare I. in Roman times.

\section{Meymart series, Savoie}

Samples from settlement, central part of Le Bourget Lake near

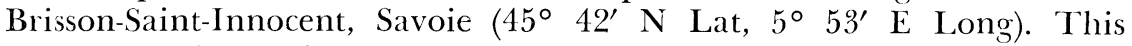
site is complex and presents several successive occupations. 
$4060 \pm 120$

Ly-190. Meymart, 59 C1

2110 B.C.

Fragment of wooden cup from supposed Chalcolithic part of site. Comment (R.L.): date confirms Chalcolithic attribution and agrees with Ly-20: $4150 \pm 180$ (R., 1969, v. 11, p. 115) from coastal sta. in Aiguebelette Lake.

Ly-276. Meymart, 59 C2

$2140 \pm 110$

Wood from pile foundation from S part of site. Comment (R.L.): this unexpected young pile might have been fixed by Gallo-Roman fishermen.

\section{Chatillon series, Savoie}

Samples from coastal sta. at Chatillon underlying ca. $5 \mathrm{~m}$ in $\mathrm{N}$ part of Le Bourget Lake near Chindrieux, Savoie $\left(45^{\circ} 46^{\prime} \mathrm{N}\right.$ Lat, $5^{\circ} 50^{\prime} \mathrm{E}$ Long).

Ly-274. Chatillon, 85 A4

$2670 \pm 110$ 720 B.C.

Wood from pile fixed in central part of sta. Comment (R.L.): same value as Ly-17: $2700 \pm 110$ (R., 1969, v. 11, p. 115) which confirms expected Late Bronze age.

\section{Ly-275. Chatillon, A5}

$2380 \pm 100$

Wood from isolated settlement outside sta. Comment (R.L.): settlement was built after destruction of main village, supposedly ca. 700 B.c.

\section{Sévrier series, Haute-Savoie}

Sample from coastal sta. submerged in Annecy Lake near Sévrier, Haute-Savoie ( $45^{\circ} 39^{\prime} \mathrm{N}$ Lat, $6^{\circ} 9^{\prime} \mathrm{E}$ Long).

\section{Ly-191. Sévrier, 267 A 3}

$$
2760 \pm 150
$$

Wood from inner part of pile foundation.

Ly-192. Sévrier, 267 A 4

$3030 \pm 150$

Wood from top of another pile.

Gcneral Comment: Ly-191 and Ly-192, respectively, agree with Ly-17: $2700 \pm 100$ and Ly-9: $3060 \pm 100$ from coastal sta. Chatillon in Le Bourget Lake. Thus, occupation length of these 2 Late Bronze settlements seems the same.

\section{Neolithic and Mesolithic periods}

\section{Tureng Tepe series, Iran}

Charcoal from 2 levels of Tell Tureng Tepe near Gorgan, Iran (36 $55^{\circ} \mathrm{N}$ Lat, $54^{\circ} 35^{\prime}$ E Long). Coll. 1963 and subm. 1968 by J. Deshayes, Fresnes, Hauts-de-Seine. 
Ly-97. Tureng Tepe, No. 3

Sample from Level 12.

Ly-96. Tureng Tepe, No. 1

Sample from Level 15.
$4550 \pm 140$

2600 B.C.

$4400 \pm 130$

2450 в.c.

General Comment: allowing for statistical errors, both dates may agree with Gif-301: $4325 \pm 250$, from Level 14 and with Gif-302: $4090 \pm$ 250 from Level 18, and these 4 values with stratigraphic order of levels.

\section{Ly-229. Les Romains, Ain} $5700 \pm 100$

Charcoal from Level E14 N. Part of site La Grotte des Romains near Virignien, Ain ( $45^{\circ} 41^{\prime} \mathrm{N}$ Lat, $5^{\circ} 21^{\prime} \mathrm{E}$ Long). Coll. and subm. by $\mathrm{R}$. Desbrosse, Blanzy, Saōne et Loire. Comment (R.D.): agrees well with assoc. Neolithic industry.

\section{Ly-264. Les Hotteaux, Ain}

$5950 \pm 340$

Small fragments of charcoal extracted from calcareous tuffa from grotto Les Hotteaux near Rossillon, Ain $\left(45^{\circ} 41^{\prime} \mathrm{N}\right.$ Lat, $5^{\circ} 35^{\prime} \mathrm{E}$ Long) Coll. 1963 and subm. 1968 by R. Vilain. Comment (R.V.): expected age was Magdalenian or Azilian but stratigraphic relationship between tuffa and industries is not established.

\section{Culoz Sous Balme series, Ain}

Charcoal from several levels in rock-shelter Sous-Balme near Culoz, Ain ( $45^{\circ} 51^{\prime} \mathrm{N}$ Lat, 5 $5^{\circ} 47^{\prime} \mathrm{E}$ Long). Coll. and subm. 1968 by R. Vilain (1966).

\section{Ly-288. Culoz Sous Balme, $W$ site, Level $3 \quad 4600 \pm 480$}

Comment (R.V.): may be little too young but agrees with Neolithic assoc. industry.

\section{Ly-289. Culoz Sous Balme, W site, Level 1}

$7360 \pm 1080$

Comment (R.V.): despite large statistical error due to small sample, date fits with assoc. Sauveterrian industry.

Ly-286. Culoz Sous Balme, E shelter, Level 1E $\quad \begin{array}{ll}\mathbf{7 2 0 0} \pm 160 \\ \text { B. }\end{array}$

Comment (R.V.): in good agreement with age expected by assoc. Sauveterrian triangles and microburins.

Ly-287. Culoz Sous Balme, E shelter, Level 3E 2640 в.C.

Comment (R.V.): Level 3E underlying Level 1E, Ly-287 confirms contamination from overlying levels as suspected during excavation.

\section{La Brèche au Diable and Longrais series, Calvados}

Charcoal from several levels at Chasséan settlement, La Brèche au 
Diable and Rubané Récent site (Danubian) Les Longrais. Both sites near Soumont-Saint-Quentin, Calvados (48 $39^{\prime} \mathrm{N}$ Lat, $0^{\circ} 13^{\prime} \mathrm{W}$ Long). Coll. 1966 and subm. 1967 by B. Edeine.

\section{Ly-134. La Brèche au Diable, Layer m, Level-97 $2610 \pm 12$}

Ly-135. La Brèche au Diable, Layer n, Level-102 2990 B.c.

Ly-148. La Brèche au Diable, Layer p, Level-110 2590 B.c.

$5140 \pm 140$

Ly-149. La Brèche au Diable, Layer q, Level-116 3190 B.c.

Comment (B.E.): these 4 values confirm relatively old age attributed to Chasséan of Normandie by Gsy-39: $4790 \pm 150$ (R., 1966, v. 8, p. 131). They prove settlement was occupied for at least ca. $500 \mathrm{yr}$.

\section{Ly-150. Les Longrais, Hole X 7, Layer a}

Comment (B.E.): this age for Rubané Récent (Danubian) seems to correspond with Neuvy en Dunnois incinerations (Gif-785: $5250 \pm 140$ B.P.) which might be also Danubian (Masset, 1968).

General Comment (B.E.): comparing Ly-150 and Ly-149, there is no interruption between Rubané Récent and Chasséan in Normandie; dates "Cerny" civilization underlying Chasséan at La Brèche au Diable (Edeine, 1970).

Ly-164. La Baume Loire 2, Haute Loire

$3670 \pm 130$

1720 B.C.

Charcoal from overlying level in rock-shelter La Baume Loire, near Solignac, Haute Loire (44 $56^{\prime} \mathrm{N}$ Lat, $3^{\circ} 54^{\prime} \mathrm{E}$ Long). Coll. and subm. 1968 by A. Crémilleux, Le Monastier sur Gazeille, Haute Loire. Comment (A.C.): agrees well with assoc. Late Neolithic industry; comparison with Ly-50: $4230 \pm 300$ (R., 1969, v. 11, p. 116) shows occupation time of site for Middle and Late Neolithic.

\section{Le Rond du Lévrier séries, Haute Loire}

Charcoal from levels at rock-shelter Le Rond du Lévrier, near Salette, Haute Loire (44. $51^{\prime} \mathrm{N}$ Lat, $3^{\circ} 58^{\prime} \mathrm{E}$ Long). Coll. and subm. 1968 by J. P. Daugas and A. Crémilleaux.

Ly-194. Le Rond du Lévrier, Level III

$3370 \pm 210$

Ly-194. Le Rond du Lévrier, Level III 1420 B.C.

Ly-195. Le Rond du Lévrier, Level IIb

$3570 \pm 130$

Ly-196. Le Rond du Lévrier, Level I 1620 B.C.

$4380 \pm 280$ 2430 B.C.

General Comment (A.C.): Ly-196 comes from same Middle Neolithic level as Ly-82: $4750 \pm 300$ (R., 1969, v. 11, p. 115). Comparison between 
Ly-196 and Ly-194, assoc. with metallic remains, shows a site occupation $>1000$ yr long. Ly-195 comes from another part of the site; its assoc. Late Neolithic industry shows Mediterranean influences.

\section{Prélétang series, Isère}

Charcoal from several sectors of upper layers in long cave, Prélétang, near Presle, Isère $\left(45^{\circ} 05^{\prime} \mathrm{N}\right.$ Lat, $5^{\circ} 25^{\prime} \mathrm{E}$ Long). Coll. and subm. by P. Lequatre, Saint-Marcellin, Isère. Lower layers of site contain a large Ursuslic. Spelaeus fauna assoc. with Mousterian industry (Lequatre, 1966). See Ly-167, this list.

\section{Ly-118. Prélétang No. 4, Sector XIII}

Modern

Comment: charcoal from upper stalagmitic floor in which branch traces demonstrate a temporary occupation.

\section{Ly-81. Prélétang No. 1, Sector XVIII}

$$
\begin{gathered}
10,400 \pm 300 \\
8450 \text { в.c. }
\end{gathered}
$$

\section{Ly-93 Prélétang No. 3, Sector XIX}

$11,730 \pm 260$

Comment on Ly-S1 and Ly-93: both samples come from bellow stalagmitic floor overlying Ursuslic. Spelaeus fauna. As expected, similar dates show that formation of stalagmitic floor began at end of Glacial time.

III. ARCHAEOLOGIC CHECK SAMPLES FOR A

NEW BONE COLLAGEN PREPARATION METHOD

The following samples were measured to test a new method of bone treatment for their dating. Many studies were made to find methods of preparation, e.g., Haynes (1966), Berger, Horney, and Libby (1964), and Kruegger (1965) that would eliminate, by different chemical processes, many contaminants which can change results. These methods have disadvantages-either treatment is too strong (contaminants are well eliminated, but very often much collagen is destroyed), or contaminants are not fully eliminated.

The method perfected and described by R. Longin (1970) consists in extracting bone collagen selectively by using one of its specific physicochemical properties-its solubility in water at a very determined temperature and $\mathrm{pH}$, after an acid pretreatment of bones. Bones, after crushing, are attacked with a solution of $\mathrm{HCl} 8 \%$ to eliminate the most important part of mineral substances (especially carbonates) and one of the main contaminants of fossil bones; pretreatment time is limited for not rendering soluble collagen. Extraction of collagen is obtained by heating and mixing the acidification residue with water at $\mathrm{pH} 3.0$, for many hours. Only collagen goes through the solution and the impurities stay in the residue. Then, collagen is recovered by drying of the solution in an oven.

The number of bones to be treated is determined by a Kjechal closage. The yield of the total extraction is about 65 to $70 \%$; it especially 
depends on crushing, acid pretreatment time, and dissolution time in water. Then, the pure gelatin obtained is burnt.

This method has the following advantages: rapidity of preparation (ca. $2 \mathrm{hr}$ ), simplicity of operations and employed substances, full elimination of contaminants, and an important yield. The technical process is fully described in the thesis and an abstract of this method will be published elsewhere.

To check the validity of dates obtained by this method (and elimination of any impurity), samples were chosen from different types of archaeologic sites (rock shelter or open air sites and calcareous or sandy layers) and the dated bones were assoc. with charcoals or burned bones on which the classical method of preparation had been made.

All measurements below show a perfect agreement between the obtained dates with bones and charcoals, and also with archaeologic data. The following table shows an easy comparison between the obtained results.

\begin{tabular}{lrrr}
\hline \multicolumn{1}{c}{ Sites } & Collagen & $\begin{array}{c}\text { Charcoal } \\
\text { residue }\end{array}$ & $\begin{array}{c}\text { Humic } \\
\text { fraction }\end{array}$ \\
\hline La Couronne Martigues & $3970 \pm 130$ & $4060 \pm 220$ & \\
Montclus layer 4 & $6140 \pm 140$ & $6300 \pm 140$ & \\
Montclus layer 21 & $7780 \pm 250$ & $7890 \pm 170$ & \\
Montclus layer 22 & $7750 \pm 340$ & $7770 \pm 410$ & \\
St Remèze 378 & $11,500 \pm 380$ & $11,750 \pm 300$ & $12,080 \pm 310$ \\
Les 2 Avens & $12,350 \pm 200$ & $12,320 \pm 600$ & \\
Solutré 9b, 8b & $17,150 \pm 300$ & $16,740 \pm 300$ & $10,900 \pm 400$ \\
St Martin sous Montaigu & $22,900 \pm 600$ & $24,150 \pm 550$ & $21,100 \pm 1300$ \\
\hline
\end{tabular}

\section{La Couronne, Bouches du Rhone series}

Samples from Layer 3D, Habitat 1 of the late Neolithic (Couronnien) village of Le Collet Redon at La Couronne, Bouches du Rhōne

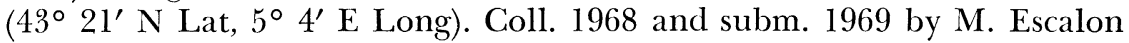
de Fonton, Marseille (Escalon de Fonton, 1956). Samples coll. $80 \mathrm{~cm}$ below a permeable calcareous soil, were subject to rain water leaching for a long time.

Ly-301. La Couronne, I/3D, charcoal

$4060 \pm 220$

Pretreatment with $\mathrm{HCl} 2 \%$ and twice $15 \mathrm{~h}$ with $\mathrm{NaOH} 2 \%$ at $80^{\circ} \mathrm{C}$.

Ly-303. La Couronne, I/3D, bone

$3970 \pm 130$

In spite of bone leaching, $300 \mathrm{~g}$ were sufficient to get $4.6 \mathrm{~g}$ of collagen. Average of Ly-301 and Ly-302: $4000 \pm 110$ в.P. $=2050$ в.C. General Comment (M.E. deF.): agrees with expected age which corresponds to desertion of village and not to its foundation. 


\section{Montclus, Gard series}

Samples from several levels of Rock-shelter La Baume de Monclus,

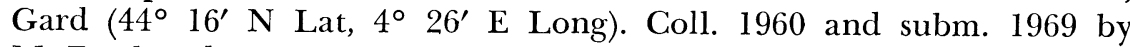
M. Escalon de Fonton. Layers contain Sauveterrian (Middle Mesolithic), Castelnovian (Late Mesolithic), Cardial and Epicardial (Late Neolithic) industries (Escalon de Fonton, 1967). Rock shelter is near La Cèze R. and deposits often overflowed.

Ly-303. Montclus, No. 3a, Layer 4, charcoal $\quad 6300 \pm 140$

Ly-304. Montclus, No. 3b, Layer 4, bone $\quad 6140 \pm 140$

$4.35 \mathrm{~g}$; collagen from $320 \mathrm{~g}$ bone. Average of Ly-303 and Ly-304: $6220 \pm 100$ B.P. $=4270$ B.C. Comment (M.E.F.): this layer contains a late Cardial industry with which date agrees well.

Ly-305. Montclus, No. 25a, Layer 21 F, charcoal $7890 \pm 170$

Ly-306. Montelus, No. 25b, Layer 21 F, bone $\quad \mathbf{7 7 8 0} \pm \mathbf{2 5 0}$

$1.8 \mathrm{~g}$; collagen from ca. $200 \mathrm{~g}$ bone. Average of Ly-303 and Ly-306: $7780 \pm 140$ в.P. $=5830$ в.C.

Ly-307. Montclus, No. 27a, Layer 22, charcoal $7770 \pm 410$

Ly-308. Montclus, No. 27b, Layer 22, bone $\quad 7750 \pm 340$

$1.5 \mathrm{~g}$ collagen from $190 \mathrm{~g}$ bone. Large statistical errors are due to small size of sample. Average of Ly-307 and Ly-308: $7760 \pm 260$ B.P. $=$ 5810 B.c. Comment on Ly-307 and Ly-308 (M.E.F.): Layers 21 F and 22 contain a regional Sauveterrian (Montclusian) industry. Dates may be compared with Kn-58: $8130 \pm 240$ from the same Layer 22. They are a little younger than Upper Sauveterrian dates at Rouffignac, Dordogne, GrN-2913: $8370 \pm 100$ (R., 1963, v. 5, p. 175).

\section{Saint Remèze, Ardèche series}

Samples from Layer D at Rock-shelter le Saut du Loup (or Abri Dumas) near Saint Remèze, Ardèche (44 $20^{\prime} \mathrm{N}$ Lat, $4^{\circ} 32^{\prime} \mathrm{E}$ Long). Coll. and subm. 1969 by J. Combier Romanèche-Thorins, Saōne et Loire. Layer contains a large rabbit fauna assoc. with Azilian industry (Combier, 1963). Samples come from $1.07 \mathrm{~m}$ below calcareous pebbles without any water circulation.

\section{Ly-318. Saint-Remèze, a) charcoal $\quad 11,750 \pm 300$ \\ Ly-319. Saint Remèze, b) humus fraction $12,080 \pm 310$ \\ Ly-320. Saint Remèze, c) bone $11,500 \pm 380$}

$155 \mathrm{~g}$ bone treated in several parts gave $2.1 \mathrm{~g}$ collagen. Average of Ly-318 and Ly-320: 11,650 \pm 240 B.P. $=9700$ B.C. Comment (J.C.): date a little older than expected with respect to regional Late Magdalenian dates (e.g., Ly-321, 322, this list). It seems very possible because this old Azilian industry might succeed to Late Magdalenian at end of Aller $\phi d$ period. 


\section{Les Deux Avens, Ardèche series}

Samples from Level C in Les Deux Avens grotto near Vallon-Pont-

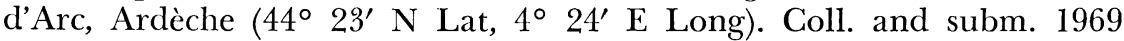
by J. Combier. Assoc. with industry precisely dated Late Magdalenian $V^{2}{ }^{2}$ and certainly before Aller $\phi d$ period (Combier, 1963). Level is inside a deep calcareous cave; it is sandy with recrystallized calcite.

\section{Ly-321. Les Deux Avens, a) charcoal \\ $12,320 \pm 600$}

Very small sample.

Ly-322. Les Deux Avens, b) bone

$12,350 \pm 200$

$5.0 \mathrm{~g}$ collagen from $545 \mathrm{~g}$ bone. Average of Ly-321 and Ly-322: $12,340 \pm 200$ B.P. $=10,390$ B.c. Comment (J.C.): agrees with other Late Magdalenian dates, as expected, just before Aller $\phi$ d period (ca. 12,000 to 11,000 B.P.) Compare with Layer 2 at La Grotte de la Vache near Alliat, Ariège, GrN-2025: 12,540 \pm 105 (R., 1963, v. 5, p. 168).

\section{Solutré series, Saone et Loire}

Samples from several places and levels of the site Solutré, Saone et Loire $\left(46^{\circ} 18^{\prime} \mathrm{N}\right.$ Lat, $4^{\circ} 43^{\prime} \mathrm{E}$ Long). Coll. and subm. 1969 by J. Combier. Site is mainly composed of a thick mass of horse bones in a large rock-rubble at foot of a limestone cliff. Some layers below a few thicknesses of soil were subject to rain-water leaching. Settlement was occupied from Mousterian to Late Magdalenian.

\section{Ly-314. Solutré No. 8 bl) \\ burned bone, residue $\quad 16,740 \pm 300$ \\ Ly-315. Solutré No. 8 b2) \\ burned bone humic fraction $\quad 10,900 \pm 400$ \\ Ly-316. Solutré No. 9 b) Unburned bone $17,150 \pm 300$}

Average of Ly-314 and Ly-316: 16,950 \pm 220 в.P. $=15,000$ в.C. Comparison between $\mathrm{Ly}-315$ and $\mathrm{Ly}-316$ proves that humic fraction is fully eliminated in bone collagen. Comment (J.C.): samples come from upper part of layer containing a Middle Solutrean industry. Date, 2000 yr younger than Middle Solutrean at Laugerie-Haute Dordogne (GrN4442: 19,600 \pm 140 , R., 1967, v. 9, p. 116). Date needs confirmation, but late age is possible in region.

\section{Ly-317. Solutré No. 11, Sondage C,}

$24,050 \pm 600$ unburned bone

Comment (J.G.): expected age was Aurignacian, but those bones may belong to Upper Perigordian layers called "Magma de Cheval". This date agrees with Dordogne, e.g., Perigordian VI at Abri Pataud, GrN-4721: 23,010 \pm 170 (R., 1967, v. 9, p. 114) and agrees also with Saint-Martin Sous Montaigu, Ly-309-311. 
Ly-12. Solutré No. 4, Layer 6, $28,650 \pm 1100$ small unburned broken bones

26,700 в.C.

$3.4 \mathrm{~g}$ collagen from $300 \mathrm{~g}$ bone.

Ly-313. Solutré No. 5, Layer 6, unburned bone $22,650 \pm 500$

$3.5 \mathrm{~g}$ collagen from $300 \mathrm{~g}$ bone. Comment (J.C.): both samples from Upper Perigordian "Magma de Cheval” level. Ly-313 agrees with Ly-317. Ly-312 is too old but these small bones come from a place in site where they might be mixed with older small bones (may be Aurignacian).

\section{Saint Martin Sous Montaigu series, Saone et Loire}

Samples from hearth at Les Vignes du Chateau Beau, near Saint Martin sous Montaigu, Saōne et Loire ( $46^{\circ} 49^{\prime}$ N Lat, $4^{\circ} 42^{\prime}$ E Long). Coll. and subm. by J. Combier. Site is similar and close to Solutré. Samples were from level resembling "Magma de Cheval" of Solutré and assoc. with Upper Perigordian Pointe de Font-Robert faciès (Combier, 1962).

Ly-309. Saint Martin Sous Montaigu,

a) burned bone residue

$24,150 \pm 550$

Ly-310. Saint Martin Sous Montaigu,

b) burned bone humic fraction $\quad 21,100 \pm 1300$

Ly-311. Saint Martin Sous Montaigu,

c) unburned bone

$22,900 \pm 600$

Average of Ly-309 and Ly-311: 23,550 \pm 400 B.P. $=21,600$ B.C. Comparison between Ly-310 and Ly-311 proves full elimination of humic fraction by bone collagen preparation. Comment (J.C.): agrees with expected age and confirms similarity with "Magma de Cheval" level of Solutré. Compare with Ly-317 and with Layer 3, Lens 2a, Abri Pataud, GrN-4721: 23,010 \pm 170 (R., 1967, v. 9, p. 114).

\section{Abri Pataud series, Dordogne}

Unburned bone from Layer 5 (Perigordian IV) at Abri Pataud, near Les Eyzies, Dordogne (44 $56^{\prime} \mathrm{N}$ Lat, $1^{\circ} 0^{\prime} \mathrm{E}$ Long). Coll. by H. L. Movius and subm. 1968 by J. C. Lerman, Radiocarbon Lab., Groningen. That sample previously measured, GrN-4631: 21,780 \pm 215 (R., 1967, v. 9, p. 114) was estimated too young with respect to other measurements $5000 \mathrm{yr}$ older from same Level 5 .

Ly.100. Abri Pataud, Layer 5, No. 1

$23.800=800$

Collagen extracted by $\mathrm{H}_{2} \mathrm{SO}_{4}$ and $\mathrm{Na}_{2} \mathrm{SO}_{4}$.

$$
21,850 \text { B.C. }
$$

Ly-300. Abri Pataud, Layer 5, No. 2

$22,000 \pm 1000$ 20,050 в.C.

Collagen extracted by method described above. Comment: Ly-300 agrees better than Ly-100) with GrN-4631. Both new values confirm younger than expected age of that sample. 


\section{Prélétang series, Isère}

Very calcified bones, from Mousterian Ursuslic. Spelaeus level in Grotte de Prélétang near Presle, Isère $\left(45^{\circ} 04^{\prime} \mathrm{N}\right.$ Lat, $5^{\circ} 25^{\prime} \mathrm{E}$ Long). Coll. and subm. 1969 by P. Lequatre, Saint-Marcellin, Isère.

Ly-167. Prélétang, Layer 9, bone collagen fraction $\geqslant 32,000$ Ca. $2 \mathrm{~g}$ collagen from $100 \mathrm{~g}$ bone.

\section{Ly-167 bis. Prélétang, Layer 9, bone carbonate fraction}

Comment: amount of collagen shows that calcification by recent water (Ly-167 bis) did not affect bone organic fraction. Null activity of Ly-167 proves that bone collagen extraction method eliminates carbonate fraction completely.

\section{Le Chène series, Vaucluse}

IV. WATER SAMPLES

The following samples were pumped from a well at Le Chène near Apt, Vaucluse $\left(43^{\circ} 4 \mathrm{I}^{\prime} \mathrm{N}\right.$ Lat, $5^{\circ} 20^{\prime} \mathrm{E}$ Long) in 1968 and 1969 to practice a periodical $\mathrm{C}^{14}$ and $\mathrm{T}^{3}$ surveillance. This well, bored at the end of 1967, gives water from the old-water reserve which contributes to the feeding of the huge intermittent spring, Fontaine de Vaucluse, at the low-water period (Margrita et al., 1970). $\delta \mathrm{C}^{13}$ was measured by R. Letolle, Lab. de Géol. Dynamique, Fac. Sci., Paris. Results are given as \% of modern without any correction.

\begin{tabular}{lccc}
\hline \multicolumn{1}{c}{ Sample } & $\begin{array}{c}\text { Collection date } \\
\text { (mo/day/yr) }\end{array}$ & C 13 & $\begin{array}{c}\mathrm{C}^{14} \\
(\% \text { of modern) }\end{array}$ \\
\hline Ly-98. Le Chène I & $4 / 17 / 68$ & & $35.5 \% \pm 1.0$ \\
Ly-99. Le Chène II & $4 / 17 / 68$ & $-8.80 \% 0$ & $48.5 \% \pm 1.1$ \\
Ly-136. Le Chène III & $11 / 13 / 68$ & & $39.9 \% \pm 0.9$ \\
Ly-137. Le Chène IV & $11 / 13 / 68$ & & $49.3 \% \pm 1.2$ \\
Ly-184. Le Chène V & $03 / 05 / 69$ & $-9.19 \%$ & $48.8 \% \pm 1.3$ \\
Ly-230. Le Chène VI & $04 / 30 / 69$ & & $44.1 \% \pm 0.8$ \\
Ly-231. Le Chène VII & $07 / 09 / 69$ & & $43.7 \% \pm 0.8$ \\
Ly-244. Le Chène VIII & $10 / 28 / 69$ & & $46.8 \% \pm 1.7$ \\
Ly-245. Le Chène IX & $11 / 17 / 69$ & & $45.1 \% \pm 0.8$ \\
\hline
\end{tabular}

General Comment: first values (Le Chène I to Le Chène IV) show perturbations caused by boring the well. Afterwards, $\mathrm{C}^{14}$ content of the water remains constant (ca. $45 \%$ of modern), but $T^{3}$ values show mixing with ca. $20 \%$ of modern water in the well.

\section{Ly-138. Fontaine de Vaucluse}

$93.8 \pm 1.6 \%$ of modern

Water from the spring Fontaine de Vaucluse $\left(13^{\circ} 44^{\prime} \mathrm{N}\right.$ Lat, $5^{\circ}$ ()' 7 E Long) coll. 1968 by J. Evin. Comment: may be compared to Ly-29: 
$91.5 \pm 3.0 \%$ and Ly-30: $93.7 \pm 3.0 \%$, both samples coll. in 1967 (R., 1969, v. 11, p. 116).

\section{Ground water of the Albien in the Paris Bassin series}

Measurements listed here were made in 1966-1970 in a hydrogeologic study of confined ground water of the Albien in the Paris Bassin. This study, set up by the Bureau de Recherches Géol. et Min., (which assumed financial support), was made to test the use of $\mathrm{C}^{14}$ in a wide (several hundred $\mathrm{km}^{2}$ ) and sandy aquifer.

Selection of sampling points, samplings, supervision of chemical preparations and hydrogeologic and chemical studies were made by Y. Vuillaume, of the Bureau La Source-Orléans, Loiret.

Most samples were treated classically by metallic tank to precipitate $\mathrm{BaCO}_{3}$ at the sampling place. But for Ly-224/249-247/250-223/248, the $\mathrm{CO}_{2}$ was extracted from the water by acidification in the radiocarbon lab. to test the tank for pollution which could be sensitive in case of low activity. Almost all the samples come from the Albien aquifer, except Ly-66, 67, 188, 221, and 203 which come from an underlying aquifer, and Ly-225 and 227, from an overlying one.

Radiocarbon content is reported as $\%$ of modern without correction from the $\delta \mathrm{C}^{13}$ measured by $\mathrm{R}$. Letolle.

\section{SE region: Bourgogne}

\begin{tabular}{|c|c|c|c|}
\hline Sample & $\begin{array}{l}\text { Collection } \\
\text { date }\end{array}$ & $\mathrm{C}^{13}$ & $\begin{array}{c}\mathrm{C}^{14} \\
\% \text { of modern }\end{array}$ \\
\hline $\begin{array}{l}\text { Ly-21. Parly-Chenons Alb2 } \\
\left(47^{\circ} 46^{\prime} \mathrm{N} \text { Lat, } 3^{\circ} 21^{\prime} \mathrm{E} \text { Long }\right)\end{array}$ & $10 / 66$ & & $94.7 \pm 0.7$ \\
\hline $\begin{array}{l}\text { Ly-32. Parly-Bernier Alb4 } \\
\left(47^{\circ} 46^{\prime} \mathrm{N} \text { Lat, } 3^{\circ} 21^{\prime} \text { E Long }\right)\end{array}$ & $10 / 66$ & & $86.7 \pm 0.7$ \\
\hline $\begin{array}{l}\text { Ly-22. Poilly S/Thollon Alb3 } \\
\left(47^{\circ} 52^{\prime} \mathrm{N} \text { Lat, } 3^{\circ} 23^{\prime} \mathrm{E} \text { Long) }\right.\end{array}$ & $10 / 66$ & & $91.7 \pm 1.0$ \\
\hline $\begin{array}{l}\text { Ly-226. Dracy } 401 \\
\left(47^{\circ} 45^{\prime} \mathrm{N} \text { Lat, } 3^{\circ} 15^{\prime} \text { E Long }\right)\end{array}$ & $7 / 69$ & $-13.9 \%$ & $66.7 \pm 1.0$ \\
\hline $\begin{array}{l}\text { Ly-213. Chichery } 397 \\
\left(47^{\circ} 54^{\prime} \mathrm{N} \text { Lat, } 3^{\circ} 31^{\prime} \mathrm{E} \text { Long) }\right.\end{array}$ & $4 / 66$ & $-17.7 \%$ & $53.2 \pm 1.8$ \\
\hline $\begin{array}{l}\text { Ly-208. Chichery } 391 / 395 \\
\left(47^{\circ} 54^{\prime} \mathrm{N} \text { Lat, 3 } 31^{\prime} \mathrm{E} \text { Long }\right)\end{array}$ & $7 / 69$ & $-13.0 \%$ & $58.0 \pm 1.1$ \\
\hline $\begin{array}{l}\text { Ly-85. Migennes } 263 \\
\left(47^{\circ} 58^{\prime} \mathrm{N} \text { Lat, } 3^{\circ} 31^{\prime} \mathrm{E} \text { Long }\right)\end{array}$ & $10 / 67$ & & $46.6 \pm 1.0$ \\
\hline $\begin{array}{l}\text { Ly-210. Migennes } 392 \\
\left(47^{\circ} 58^{\prime} \mathrm{N} \text { Lat, } 3^{\circ} 21^{\prime} \mathrm{E} \text { Long }\right)\end{array}$ & $7 / 69$ & & $67.3 \pm 0.9$ \\
\hline
\end{tabular}




\begin{tabular}{|c|c|c|c|}
\hline Sample & $\begin{array}{l}\text { Collection } \\
\text { date }\end{array}$ & $\mathrm{C}^{13}$ & $\begin{array}{c}\mathrm{C}^{14} \\
\% \text { of modern }\end{array}$ \\
\hline $\begin{aligned} \text { Ly-108. } & \text { Montbouy } 262 / 269 \\
\left(47^{\circ}\right. & \left.52^{\prime} \text { N Lat, } 2^{\circ} 49^{\prime} \text { E Long }\right)\end{aligned}$ & $10 / 67$ & & $28.9 \pm 0.5$ \\
\hline $\begin{array}{ll}\text { Ly-186. } & \text { Neuilly } 371 / 374 \\
\left(48^{\circ}\right. & \left.04^{\prime} \text { N Lat, } 3^{\circ} 25^{\prime} \text { E Long }\right)\end{array}$ & $3 / 69$ & & $15.9 \pm 0.6$ \\
\hline $\begin{array}{l}\text { Ly-109. Fleury } 268 \\
\left(47^{\circ} 52^{\prime} \mathrm{N} \text { Lat, } 3^{\circ} 26^{\prime} \text { E Long }\right)\end{array}$ & $11 / 67$ & & $14.9 \pm 0.7$ \\
\hline $\begin{array}{l}\text { Ly-187. Champvallon } 375 / 376 \\
\left(47^{\circ} 56^{\prime} \mathrm{N} \text { Lat, } 3^{\circ} 20^{\prime} \text { E Long }\right)\end{array}$ & $3 / 69$ & $-12.8 \%$ & $13.6 \pm 0.7$ \\
\hline $\begin{array}{l}\text { Ly-66. Appoigny } 264 \text { A } \\
\left(47^{\circ} 53^{\prime} \mathrm{N} \mathrm{Lat,} 3^{\circ} 31^{\prime} \text { E Long }\right)\end{array}$ & $10 / 67$ & & $12.7 \pm 1.0$ \\
\hline $\begin{array}{l}\text { Ly-67. Appoigny } 264 \text { B } \\
\left(47^{\circ} 53^{\prime} \mathrm{N} \text { Lat, } 3^{\circ} 31^{\prime} \text { E Long }\right)\end{array}$ & $10 / 67$ & & $11.6 \pm 0.8$ \\
\hline $\begin{array}{l}\text { Ly-188. Appoigny } 377 / 378 \\
\left(47^{\circ} 53^{\prime} \text { N Lat, } 3^{\circ} 31^{\prime} \text { E Long }\right)\end{array}$ & $3 / 69$ & $-18.3 \%$ & $0.6 \pm 0.4$ \\
\hline $\begin{array}{l}\text { Ly-86. Grande Paroisse } 258 \\
\left(48^{\circ} 23^{\prime} \text { N Lat, } 2^{\circ} 35^{\prime} \text { E Long }\right)\end{array}$ & $10 / 67$ & & $10.6 \pm 0.6$ \\
\hline $\begin{aligned} & \text { Ly-125. } \text { Grande Paroisse } 304 / 305 \\
&\left(48^{\circ} 23^{\prime} \mathrm{N} \text { Lat, } 2^{\circ} 35^{\prime} \mathrm{E} \text { Long }\right)\end{aligned}$ & $3 / 68$ & & $9.5 \pm 0.8$ \\
\hline $\begin{array}{l}\text { Ly-228. } \\
\left(48^{\circ} 23^{\prime} \text { N Lat, } 2^{\circ} 35^{\prime} \text { E Long }\right)\end{array}$ & $7 / 69$ & $-10.2 \%$ & $3.2 \pm 0.5$ \\
\hline $\begin{array}{l}\text { Ly-209. Bussy en Othe } 393 \\
\left(48^{\circ} 01^{\prime} \mathrm{N} \text { Lat, } 3^{\circ} 30^{\prime} \text { E Long }\right)\end{array}$ & $7 / 69$ & $-10.2 \%$ & $4.5 \pm 0.4$ \\
\hline $\begin{aligned} \text { Ly-225. } & \text { Grand-Chaumont } 402 \\
\left(47^{\circ}\right. & \left.51^{\prime} \text { N Lat, } 3^{\circ} 19^{\prime} \text { E Long }\right)\end{aligned}$ & $7 / 69$ & $-13.2 \%$ & $95.6 \pm 1.1$ \\
\hline $\begin{aligned} \text { Ly-227. } & \text { Froville } 400 \\
\left(47^{\circ}\right. & \left.5 \mathrm{l}^{\prime} \mathrm{N} \text { Lat, } 3^{\circ} 16^{\prime} \mathrm{E} \text { Long }\right)\end{aligned}$ & $7 / 69$ & $-12.7 \%$ & $72.5 \pm 0.9$ \\
\hline \multicolumn{4}{|c|}{ E region: Champagne } \\
\hline $\begin{array}{l}\text { Ly-219. Nuisement } 387 \\
\left(48^{\circ} 35^{\prime} \text { N Lat, } 4^{\circ} 44^{\prime} \text { E Long }\right)\end{array}$ & $6 / 69$ & $-11.7 \%$ & $84.3 \pm 1.1$ \\
\hline 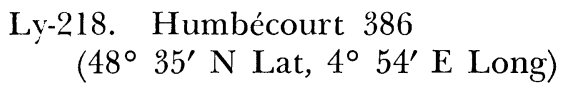 & $6 / 69$ & $-12.1 \%$ & $76.9 \pm 0.8$ \\
\hline $\begin{aligned} & \text { Ly-222. } \text { Chaudefontaine } 390 \\
&\left(49^{\circ} 66^{\prime} \mathrm{N} \text { Lat, } 4^{\circ} 52^{\prime} \mathrm{E} \text { Long }\right)\end{aligned}$ & $6 / 69$ & $-13.3 \%$ & $74.8 \pm 0.9$ \\
\hline $\begin{aligned} \text { Ly-220. } & \text { Voilecomte } 388 \\
\left(48^{\circ}\right. & \left.41^{\prime} \text { N Lat, } 4^{\circ} 51^{\prime} \text { E Long }\right)\end{aligned}$ & $6 / 69$ & $-14.8 \%$ & $66.3 \pm 1.0$ \\
\hline
\end{tabular}




\begin{tabular}{|c|c|c|c|c|}
\hline & Sample & $\begin{array}{l}\text { Collection } \\
\text { date }\end{array}$ & $\mathrm{C}^{13}$ & $\begin{array}{c}\mathrm{C}^{14} \\
\% \text { of modern }\end{array}$ \\
\hline $\begin{aligned} \mathrm{Ly}-217 . \\
\left(48^{\circ}\right.\end{aligned}$ & $\begin{array}{l}\text { Montier en Der } 385 \\
29^{\prime} \mathrm{N} \text { Lat, } 4^{\circ} 46^{\prime} \text { E Long) }\end{array}$ & $6 / 69$ & & $52.8 \pm 0.8$ \\
\hline $\begin{aligned} \text { Ly-2 } 216 . \\
$\[ \left(48^{\circ}\right. \]$\end{aligned}$ & $\begin{array}{l}\text { Dompremy } 384 \\
44^{\prime} \text { N Lat, } 4^{\circ} 43^{\prime} \text { E Long) }\end{array}$ & $6 / 69$ & $-9.0 \%$ & $17.9 \pm 0.9$ \\
\hline $\begin{aligned} & \mathrm{Ly}-221 . \\
&\left(49^{\circ}\right.\end{aligned}$ & $\begin{array}{l}\text { Sainte Menehould } 389 \\
06^{\prime} \text { N Lat, } 4^{\circ} 53^{\prime} \text { E Long) }\end{array}$ & $6 / 69$ & & $1.4 \pm 0.4$ \\
\hline
\end{tabular}

$S$ and $W$ regions: Orléannais and Normandie

\begin{tabular}{|c|c|c|c|}
\hline $\begin{array}{l}\text { Ly-71. Barlieu } 266 \\
\left(47^{\circ} 30^{\prime} \text { N Lat, } 2^{\circ} 38^{\prime} \text { E Long }\right)\end{array}$ & $10 / 67$ & & $82.1 \pm 1.3$ \\
\hline $\begin{array}{l}\text { Ly-205. Bemecourt } 381 \\
\left(48^{\circ} 51^{\prime} \mathrm{N} \text { Lat, } 0^{\circ} 53^{\prime} \text { E Long }\right)\end{array}$ & $5 / 69$ & $-13.7 \%$ & $75.5 \pm 1.0$ \\
\hline $\begin{array}{l}\text { Ly-204. Thiberville } 380 \\
\left(49^{\circ} 08^{\prime} \mathrm{N} \text { Lat, } 0^{\circ} 27^{\prime} \text { E Long }\right)\end{array}$ & $5 / 69$ & $-13.0 \%$ & $65.3 \pm 0.8$ \\
\hline $\begin{array}{l}\text { Ly-206. Brou } 382 \\
\left(48^{\circ} 13^{\prime} \text { N Lat, } 1^{\circ} 10^{\prime} \text { E Long }\right)\end{array}$ & $5 / 69$ & $-9.0 \%$ & $52.0 \pm 0.8$ \\
\hline $\begin{array}{l}\text { Ly-207. Chateaudun } 383 \\
\left(48^{\circ} 03^{\prime} \text { N Lat, } 1^{\circ} 24^{\prime} \text { E Long }\right)\end{array}$ & $5 / 69$ & $-5.7 \%$ & $40.9 \pm 0.8$ \\
\hline $\begin{array}{l}\text { Ly-74. Blancafort } 267 \\
\left(47^{\circ} 32^{\prime} \text { N Lat, } 2^{\circ} 32^{\prime} \text { E Long }\right)\end{array}$ & $10 / 67$ & & $42.2 \pm 1.2$ \\
\hline Ly-111. La Chapelle d'Ang & $11 / 67$ & & $34.2 \pm 0.9$ \\
\hline
\end{tabular}

(472' $\mathrm{N}$ Lat, $2^{\circ} 26^{\prime} \mathrm{E}$ Long)

NW regions: Haute-Normandie

\begin{tabular}{|c|c|c|c|}
\hline 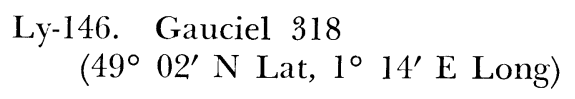 & $7 / 68$ & $-9.9 \%$ & $37.5 \pm 0.8$ \\
\hline $\begin{array}{l}\text { Ly-141. Le Marais Vernier } 326 \\
\left(49^{\circ} 26^{\prime} \text { N Lat, } 0^{\circ} 28^{\prime} \text { E Long }\right)\end{array}$ & $7 / 68$ & $-14.3 \%$ & $36.9 \pm 0.9$ \\
\hline $\begin{array}{l}\text { Ly-147. Vernon } 317 \\
\left(49^{\circ} 06^{\prime} \text { N Lat, } 1^{\circ} 26^{\prime} \text { E Long }\right)\end{array}$ & $7 / 68$ & $-8.3 \%$ & $21.7 \pm 0.6$ \\
\hline $\begin{array}{l}\text { Ly-144. Les Loges } 322 \\
\left(49^{\circ} 42^{\prime} \mathrm{N} \text { Lat, } 0^{\circ} 17^{\prime} \text { E Long }\right)\end{array}$ & $7 / 68$ & $-9.6 \%$ & $15.9 \pm 0.4$ \\
\hline $\begin{array}{l}\text { Ly-143. Saint Pierre en Port } 323 \\
\left(49^{\circ} 48^{\prime} \mathrm{N} \text { Lat, } 0^{\circ} 29^{\prime} \text { E Long }\right)\end{array}$ & $8 / 68$ & $-11.4 \%$ & $16.0 \pm 2.0$ \\
\hline $\begin{aligned} \text { Ly-145. } & \text { Le Trait } 319 \\
\left(49^{\circ}\right. & \left.28^{\prime} \text { N Lat, } 0^{\circ} 49^{\prime} \text { E Long }\right)\end{aligned}$ & $7 / 68$ & $-10.9 \%$ & $12.4 \pm 0.7$ \\
\hline
\end{tabular}




\begin{tabular}{|c|c|c|c|}
\hline Sample & $\begin{array}{l}\text { Collection } \\
\text { date }\end{array}$ & $\mathbf{C}^{13}$ & $\begin{array}{c}\mathrm{C}^{14} \\
\% \text { of modern }\end{array}$ \\
\hline $\begin{array}{l}\text { Ly-215. Mantes } 399 \\
\left(48^{\circ} 59^{\prime} \text { N Lat, } 1^{\circ} 40^{\prime} \text { E Long }\right)\end{array}$ & $3 / 69$ & & $11.8 \pm 1.4$ \\
\hline $\begin{array}{l}\text { Ly-110. Pont de l'Arche } 272 \\
\left(49^{\circ} 18^{\prime} \mathrm{N} \text { Lat, } 1^{\circ} 09^{\prime} \mathrm{E} \text { Long }\right)\end{array}$ & $11 / 67$ & & $7.2 \pm 0.7$ \\
\hline $\begin{array}{l}\text { Ly-181. Honfleur } 325 \\
\left(49^{\circ} 25^{\prime} \mathrm{N} \text { Lat, } 0^{\circ} 14^{\prime} \mathrm{E} \text { Long }\right)\end{array}$ & $7 / 68$ & $-13.3 \%$ & $78.6 \pm 1.4$ \\
\hline $\begin{array}{l}\text { Ly-142. Le Crotoy } 324 \\
\left(50^{\circ} 13^{\prime} \text { N Lat, } 3^{\circ} 04^{\prime} \text { E Long }\right)\end{array}$ & $7 / 68$ & $-17.1 \%$ & $31.7 \pm 0.9$ \\
\hline Ly-203. Incarville 379 & $5 / 69$ & $+2.9 \%$ & $1.4 \pm 0.4$ \\
\hline
\end{tabular}

Central region: Ile de France

Ly-121. Epinay 298

(485 $57^{\prime} \mathrm{N}$ Lat, $2^{\circ} 19^{\prime} \mathrm{E}$ Long)

Ly-40. Villeneuve La Garenne 236 (48 $56^{\prime} \mathrm{N}$ Lat, $2^{\circ} 20^{\prime} \mathrm{E}$ Long)

Ly-124. Achères 302

(48 $58^{\prime} \mathrm{N}$ Lat, $1^{\circ} 53^{\prime}$ E Long)

Ly-119. Ivry

( $48^{\circ} 49^{\prime} \mathrm{N}$ Lat, $2^{\circ} 23^{\prime}$ E Long)

Ly-120. Orsay 284

(48 $43^{\prime} \mathrm{N}$ Lat, $2^{\circ} 10^{\prime}$ E Long)

Ly-126. Le Pecq 303

(48 $53^{\circ}$ N Lat, $2^{\circ} 06^{\prime} \mathrm{E}$ Long)

Ly-37. Pantin 214/226

(48 $54^{\prime} \mathrm{N}$ Lat, $2^{\circ} 15^{\prime}$ E Long)

Ly-211. Issy 394

(48 $50^{\prime}$ N Lat, $2^{\circ} 16^{\prime} \mathrm{E}$ Long)

Ly-122. Noisy le Grand 299
$\left(48^{\circ} 48^{\prime} \mathrm{N}\right.$ Lat, $2^{\circ} 32^{\prime} \mathrm{E}$ Long $)$

Ly-224/249. Noisy le Grand L. 310

( $48^{\circ} 48^{\prime}$ N Lat, $2^{\circ} 32^{\prime}$ E Long)

Ly-23. Paris O.R.T.F. Albl
$\left(48^{\circ} 52^{\prime}\right.$ N Lat, $2^{\circ} 18^{\prime}$ E Long)

Ly-214. Paris O.R.T.F. 398

(48 $52^{\circ} \mathrm{N}$ Lat, $2^{\circ} 18^{\prime} \mathrm{E}$ Long)

$\begin{array}{lll}3 / 68 & -14.2 \% \text { o } & 9.7 \pm 1.4 \\ 6 / 67 & & 9.1 \pm 0.5 \\ 3 / 68 & -16.3 \% \text { co } & 8.9 \pm 0.2 \\ 1 / 68 & -13.3 \% \text { o } & 8.5 \pm 0.1 \\ 1 / 68 & -10.7 \% \text { o } & 7.8 \pm 0.8 \\ 3 / 68 & -14.3 \% \text { o } & 7.3 \pm 1.3 \\ 12 / 66 & -15.3 \% \text { o } & 6.4 \pm 0.1 \\ 7 / 69 & -15.0 \% \text { o } & 3.7 \pm 0.4 \\ 3 / 68 & -14.1 \% \text { o } & 3.5 \pm 0.5 \\ 8 / 69 & & 3.7 \pm 0.4 \\ 10 / 66 & & 8.8 \pm 0.3 \\ 2 / 67 & -12.2 \% & 3.2 \pm 0.5\end{array}$




\begin{tabular}{|c|c|c|c|}
\hline Sample & $\begin{array}{l}\text { Collection } \\
\text { date }\end{array}$ & $\mathrm{C}^{13}$ & $\begin{array}{l}\mathrm{C}^{14} \\
\% \text { of modern }\end{array}$ \\
\hline $\begin{aligned} & \text { Ly-123. } \text { Aulnay Sous Bois } 300 \\
&\left(48^{\circ} 57^{\prime} \mathrm{N} \text { Lat, } 2^{\circ} 30^{\prime} \text { E Long }\right)\end{aligned}$ & $3 / 68$ & $-16.4 \%$ & $2.7 \pm 0.1$ \\
\hline $\begin{array}{l}\text { Ly-212. Aulnay Sous Bois } 396 \\
\left(48^{\circ} 57^{\prime} \mathrm{N} \text { Lat, } 2^{\circ} 30^{\prime} \mathrm{E} \text { Long }\right)\end{array}$ & $7 / 69$ & & $1.0 \pm 0.4$ \\
\hline $\begin{array}{r}\text { Ly-247/250. Aulnay Sous Bois L. } 382 \\
\left(48^{\circ} 57^{\prime} \text { N Lat, } 2^{\circ} 30^{\prime} \text { E Long }\right)\end{array}$ & $10 / 69$ & $-10.6 \%$ & $2.6 \pm 0.3$ \\
\hline $\begin{array}{r}\text { Ly-223/248. Viry Chatillon L. } 309 \\
\left(48^{\circ} 40^{\prime} \text { N Lat, } 2^{\circ} 23^{\prime} \text { E Long }\right)\end{array}$ & $8 / 69$ & $-12.8 \%$ & $2.1 \pm 0.5$ \\
\hline
\end{tabular}

General Comment (J.E. and Y.V.): a map of these results in isorad curves shows the feeding zones along the entire periphery of the bassin and the general flow in the direction of the central or the NW regions. In the $\mathrm{SE}$ region, great differences of radioactivity along short distances show that feeding of the reservoir occurs through clay overlying the aquifer (Evin and Vuillaume, 1970).

Ground water of the Calcaires de Champigny series, Seine et Marne

The following samples measured in 1967-1969 were sent by the Dept. d'Hydrogéol. du Bur. de Recherches Géol. et Min. All come from free ground water in the limestone Calcaire de Champigny, ca. $20 \mathrm{~km} \mathrm{SE}$ of Paris. Y. Vuillaume assumed sampling and chemical treatment.

$$
\text { Sample Collection date } \mathrm{C}^{14} \% \text { of modern }
$$

Ly-78. Brie Comte Robert $292 \quad 3 / 68 \quad 126.8 \pm 1.2$

(48 $41^{\prime}$ N Lat, $2^{\circ} 26^{\prime}$ E Long)

Ly-172. Brie Comte Robert 339

(48 $41^{\prime}$ N Lat, $2^{\circ} 26^{\prime}$ E Long)

Ly-102. Presles en Brie 286

(48 $43^{\prime} \mathrm{N}$ Lat, $2^{\circ} 44^{\prime}$ E Long)

Ly-179. Presles en Brie 330

(48 $43^{\prime} \mathrm{N}$ Lat, $2^{\circ} 44^{\prime} \mathrm{E}$ Long)

Ly-175. Mardilly 336

(4839' N Lat, $2^{\circ} 38^{\prime}$ E Long)

Ly-174. Saint Hillier 337

(48 $38^{\prime} \mathrm{N}$ Lat, $3^{\circ} 15^{\prime}$ E Long)

Ly-107. Combe la Ville 291

(48 $40^{\prime} \mathrm{N}$ Lat, $2^{\circ} 33^{\prime}$ E Long)

$1 / 69 \quad 139.2 \pm 2.0$

$3 / 68 \quad 97.6 \pm 1.5$

$1 / 69 \quad 102.6 \pm 1.6$

$1 / 69 \quad 94.7 \pm 1.5$

$1 / 69 \quad 93.0 \pm 1.4$

$3 / 68 \quad 84.7 \pm 1.5$

Ly-176. Pont du Diable 335

(483' $39^{\prime} \mathrm{N}$ Lat, $2^{\circ} 38^{\prime}$ E Long)

$1 / 69 \quad 83.2 \pm 1.4$ 
Sample

Ly-104. Rouilly 288

(48 $36^{\prime} \mathrm{N}$ Lat, $3^{\circ} 17^{\prime} \mathrm{E}$ Long)

Ly-173. Rouilly 338

(48 $36^{\prime} \mathrm{N}$ Lat, $3^{\circ} 17^{\prime} \mathrm{E}$ Long)

Ly-103. Neufmoutier 287

(48 $46^{\prime} \mathrm{N}$ Lat, $2^{\circ} 50^{\prime}$ E Long)

Ly-178. Neufmoutier 332

(484ㅇ $46^{\prime} \mathrm{N}$ Lat, $2^{\circ} 50^{\prime} \mathrm{E}$ Long)

Ly-46. Nangis 242/243

(48 $33^{\prime} \mathrm{N}$ Lat, $3^{\circ} 01^{\prime}$ E Long)

Ly-44. Nangis 249

(48 $33^{\prime} \mathrm{N}$ Lat, $3^{\circ} 01^{\prime} \mathrm{E}$ Long)

Ly-105. Nangis 289

( $48^{\circ} 33^{\prime} \mathrm{N}$ Lat, $3^{\circ} 01^{\prime}$ E Long)

Ly-101. Chevry Cossigny 285

(48 $43^{\prime} \mathrm{N}$ Lat, $2^{\circ} 41^{\prime}$ E Long)

Ly-177. Chevry Cossigny 333

(48 $43^{\circ}$ N Lat, $2^{\circ} 41^{\prime}$ E Long)
Collection date $\mathrm{C}^{14} \%$ of modern

$\begin{array}{cc}3 / 68 & 70.1 \pm 1.1 \\ 1 / 69 & 77.5 \pm 1.5 \\ 3 / 68 & 72.5 \pm 1.1 \\ 1 / 69 & 52 \pm 6 \\ 9 / 67 & 58.6 \pm 1.4 \\ 9 / 67 & 66.7 \pm 0.5 \\ 3 / 68 & 64.4 \pm 1.1 \\ 3 / 68 & 45.6 \pm 0.9 \\ 1 / 69 & 43.0 \pm 1.0\end{array}$

Samples from the same well at La Ferté Alais $\left(48^{\circ} 29^{\prime} \mathrm{N}\right.$ Lat, $2^{\circ} 21^{\prime}$ E Long).

$\begin{array}{lllr}\text { Ly-56. } & \text { La Ferté } 250 & 9 / 67 & 12.5 \pm 0.5 \\ \text { Ly-57. } & \text { La Ferté } 251 & 9 / 67 & 9.6 \pm 0.7 \\ \text { Ly-58. } & \text { La Ferté } 253 & 9 / 67 & 6.0 \pm 0.9 \\ \text { Ly-59. } & \text { La Ferté } 255 & 9 / 67 & 7.7 \pm 0.6 \\ \text { Ly-79. } & \text { La Ferté } 293 & 3 / 68 & 8.2 \pm 1.6 \\ \text { Ly-106. } & \text { La Ferté } 290 & 3 / 68 & 9.1 \pm 0.1 \\ \text { Ly-161. } & \text { La Ferté } 348 & 1 / 69 & 4.4 \pm 0.6 \\ \text { Ly-162. } & \text { La Ferté } 347 & 1 / 69 & 3.4 \pm 0.7 \\ \text { Ly-163. } & \text { La Ferté } 346 & 1 / 69 & 8.2 \pm 0.6\end{array}$

General Comment: most of these values are rather high. This fits with the fact that the ground water is free and with rather quick renewal except at La Ferté Alais, where radioactivity is low and ground water is confined without flow. 


\section{Villeneuve La Garenne series, Hauts de Seine}

Samples from Lutetien and Sparnacien aquifer at Villeneuve La Garenne ( $48^{\circ} 56^{\prime} \mathrm{N}$ Lat, $2^{\circ} 20^{\prime}$ E Long).
Sample
Collection date
$\mathrm{C}^{14} \%$ of modern

$\begin{array}{llll}\text { Ly-45. } & \text { Villeneuve-Lutetien } 235 & 9 / 67 & 58.9 \pm 1.0 \\ \text { Ly-39. } & \text { Villeneuve-Sparnacien } 234 & 9 / 67 & 56.4 \pm 1.1 \\ \text { Ly-127. } & \text { Villeneuve-Lutetien } 297 & 3 / 68 & 61.2 \pm 2.2 \\ \text { Ly-128. } & \text { Villeneuve-Sparnacien } 296 & 3 / 68 & 56.9 \pm 2.1 \\ \text { Ly-183. } & \text { Villeneuve-Lutetien } 341 & 1 / 69 & 63.3 \pm 1.2 \\ \text { Ly-180. } & \text { Villeneuve-Sparnacien } 340 & 1 / 69 & 62.8 \pm 1.0\end{array}$

REFERENCFS

Barusseau, J. P., 1969, Age probable de la mise en place des sables grossiers et cailloutis du plateau continental du golfe de Gascogne entre l'Ile de Ré et le Plateau de Rochebonne: INQUA, VIIIth Cong., Paris, 1969, in press.

Berger, R., Horney, A. G., and Libby, W. F., 1964, Radiocarbon dating of bone and shell from their organic components: Science, v. 144, p. 999-1001.

Blavoux, B. and Brun, A., 1966, Nouvclles données sur les terrains quaternaires de la région lémanique: Acad. sci. [Paris] Comptes rendus, v. 262, p. 2569-2572.

Bocquet, A. and Papet, J., 1966, La Grotte des Sarrasins: Soc. dauphinoise d'Ethnol. et Archeol. Bull., v. 66, p. 119-124.

Bourdier, Frank, 1963, Le bassin du Rhōne au Quaternaire: Thesis, Univ. of Paris.

Combier, Jean, 1962, Le gisement de Saint-Martin-sous-Montaigu: Gallia Préhist., v. 5, p. $303-304$.

1963, La Paléolithique de l'Ardèche dans son cadre paléoclimatique: Thesis, Univ. of Paris, Univ. Bordeaux Press, v. 4, p. 348-361.

Coursaget, J. and Le Run, J., 1966, Gif-sur-Yvette natural radiocarbon measurements I: Radiocarbon, v. 8, p. 128-141.

Delibrias, G., Guillier, M. T., and Labeyrie, J., 1969, Gif natural radiocarbon measurements III: Radiocarbon, v. 11, p. 327-344.

Edeine, Bernard, 1970, Nouvelles datations par le $C^{14}$ concernant la Basse-Normandie, en particulier le Chasséen et le Rubané Récent: Soc. française Préhist. Bull., v. 67 , no. 4 , p. 114-119.

Escalon de Fonton, Max, 1956, Préhistoire de la Basse Provence. Etat d'avancement des recherches en 1951: Préhist., v. 12, p. 1-154.

1967, Origine et développement des civilisations néolithiques méditerranéennes en Europe Occidentale: Palaeohistoria, v. 12, p. 209-248.

Evin, J., Longin, R., and Pachiaudi, C., 1969, Lyon natural radiocarbon measurements I: Radiocarbon, v. 11, p. 112-117.

Evin, J. and Vuillaume, Y., 1970, Etude par le Radiocarbone de la nappe captive de l'Albien du Bassin de Paris: I.A.E.A., Symposium on isotopes in hydrology, Vienna,
SM-129/19.

Haynes, C. V., 1966, Bone organic matter and radiocarbon dating: I.A.E.A., Conf. on radioactive dating and methods of low-level counting, Vienna, SM-87/56.

Jayet, Adrien, 1966, Résumé de géologie glaciaire régionale: Genève, G. Chapuis Press.

Krueger, H. W., 1965, The preservation and dating of collagen in ancient bones: 6th internatl. conf. on $\mathrm{C}^{14}$ and $\mathrm{T}^{3}$ dating Proc., Pullman, Washington, p. 332-337. Lagier-Bruno, Lucien, 1970, Le géant des Chènes de la Balme: Annales du Bugey,
v. 70, p. 54-66.

Lequatre, Paul, 1966, La grotte de Prélétang, le repaire d'ours des cavernes et son industrie moustérienne: Gallia Préhist., v. 9, no. 1, p. 1-83.

Longin, Robert, 1970, Extraction du collagène des os fossiles pour leur datation par la méthode du carbone 14: Thesis, Fac. Sci., Lyon, 70 p.

Margrita, R., Evin, J., Flandrin, J., and Paloc, H., 1970, Contribution des mesures isotopiques à l'étude de la Fontaine de Vaucluse: I.A.E.A., Symposium on isotopes in hydrology, Vienna, SM-129/20. 
Martini, J. and Duret, J. J., 1965, Etude du niveau de cendres volcaniques des sédiments post-glaciaires récents des environs de Genève: Archives des Sciences, Genève, v. 18 , no. 3 , p. $563-595$.

Masset, Claude, 1968, Les incinérations du néolithique ancien de Neuvy-en-Dunois (Eure et Loir): Gallia Préhist., v. 11, no. 1, p. 205-218.

Oeschger, H., Riesen, T., and Lerman, J. C., 1970, Bern radiocarbon dates VII: Radiocarbon, v. 12 , p. $358-384$.

Tournier, J. and Guillan, C., 1903, Les abris de Sous-Sac et les grottes de l'Ain à l'époque mésolithique: Bourg en Bresse, le Courrier de l'Ain Press.

Vilain, Robert, 1966, Le gisement de Sous-Balme à Culoz (Ain) et ses industries microlithiques: Lab. Géol., Fac. Sci., Lyon Doc., v. 13, 220 p.

Vogel, J. C. and Waterbolk, H. 'T., 1963, Groningen radiocarbon dates IV: Radiocarbon, v. 5, p. 163-202.

1967, Groningen radiocarbon dates VII: Radiocarbon, v. 9, p. 107-155. 